\title{
Impact of E-Marketing Promotions on the Performance of Religious Tourism: In Case of Srikakulam District, A.P, India
}

\author{
Koppala Venugopal, D. Vishnu Murty
}

\begin{abstract}
Collision of religion has been imperative for all kind of dexterous industries in India and tourism being considered as one of the profitable industries, amalgamation of religion with tourism has been identified as the most important element. To be specific and integrated as far as the marketing promotions are considered, technology which aids the promotion with respect to social media, e-mail marketing and digital marketing techniques has now a days play a vital role in line with effective reach and message impact. Researchers have aimed to evaluate the impression of e-marketing promotion mix of religious tourism on the performance of tourism in Srikakulam District where many holy destinations such as Arasavilli, Srikurmam and Srimukhalingametc exist. An exploratory and descriptive research design with convenience sampling aiming at the respondents of digitally habituated devotees in the very popular social media and other with a structured questionnaire and focus group discussions have been conducted. The results drawn with the help of SPSS 20 have been analyzed and interpreted that have shown the accustomisation of digital information seeking among different demographical groups of devotees with respect to e-marketing, transportation, accommodation and other celestial activities such as libation and poojas. Recommendations by the researcher have been offered to different communities related with tourism industry. This paper will be an advantage especially for endowment department of the government by considering the finding and conclusions of the study which are associated with all integrated promotions of $e$ marketing and marketing skill applications.
\end{abstract}

Keywords: Religious Tourism, Marketing Skills, E-Marketing Promotion Mix, Srikakulam

\section{INTRODUCTION}

The prominence of tourism sector in the world is evident with its growth and development with respect to its promising nature (Nurhssen, 2016; Gurung, 2016) and also has shown its significance especially in developed and developing countries where its role is imperative. As per the reports of UNWTO (2005), the efforts of poor countries has been successful for its rapid growth in tourism. In specific with categorization of religious tourism, which is reflected as the earliest practice of tourism with the values of humanity (Farhat, Ummara\&Sundas, 2016).

The increment in the growth of world tourism can be understood through UNWTO (2018) reports that the international tourist arrivals worldwide is projected and amplified with 7\% in 2017 to reach a total of 1,322 million.

Revised Manuscript Received on 14 August, 2019.

Dr. KoppalaVenugopal, Professor, Professor in Management Studies, AITAM, Tekkali, Srikakulam, AP, India (Email: koppala71@gmail.com)

Dr. D. Vishnu Murty, Dean and Professor in Management Studies, AITAM, Tekkali, Srikakulam, AP, India(Email: vishnudevi33@gmail.com)
Several nations cover religious sites that serve the cultural contingencies and contributes in the way of economic development through local industry and marketing.

Religious tourism engenders income through the money disbursed by tourists that benefits the native commercial people. Governments of both local and state along with the strategic view towards the development of residents also speed up the economic accomplishments as well (Farhat et al, 2016). Christianity, Islam, Hinduism and Buddhism being foremost religions, Christianity holds the highest with 33 percent and Muslims accounts for 19.6 percent followed by Hinduism and Buddhism which is $13.4 \%$ and $5.9 \%$ respectively (Robinson, 2015).

The growth of religion tourism in particular has been significant since 2007 with the figures found interesting that approximately 18-20 million tourists visit domestic and international destinations yearly, around 40,000 to 50,000 tourists contact with religious site daily (Petal, 2010 as cited in Melese, (2015).

Other statistics such as the approximations by the World Tourism Organization would be 300 - 330 million tourists who are enlightened with the most important sacred monuments in the world every year as well as, around 600 million journeys are made nationally and internationally which in turn carried out as a contributor of commercial activity in that place and the distribution of reciprocated values of cultures (UNWTO, 2014).

Such destinations with religious importance are yet to be promoted with novel and trendy media channels in developing countries since the destination's information in detail is not disseminated accurately, the popular channel which is caught the fancy of many people in the world now through e marketing is social media, wherein many companies promote their products and services. Additionally, it is a better platform for tourism promotion through the well-furnished information with Images, Videos, Check-Ins, hashtags, shared experiences and travels agency or trip advisor. Personal interaction and engagement with tourists, two way communication, immediate response and target market are the core competencies of social media and tourism destinations should also spare the time and money through the creative lines to impress the audience such as graphical presentations, unique features and updated designs.

Indian tourism being amalgamated with the dominance of religious and spiritual adroit, the destinations captivate a lot of visitors' attention by most of the so called traditional 
practices of promotional tool and channels for years. Researches and the recent practices elevate the importance of the social media to promote religion tourism with all the specifications since the users of social media is increasing tremendously time to time (tourism.gov.in).

Researchers of the study have selected the important destinations of Srikakulam district in Andhra Pradesh since it is known for its enriched history in line with spiritual witnesses of temples, trusts and Mosques with about 821 Institutions managed by the AP State Endowments Department. Though there are several destinations such as Sri Venkateswara Temple at NarayanaTirumala, Sri Uma RudraKoteswaraSwamy Temple, Sri SeetharamaSwamy Temple, Sri Sangameswara Temple at Sangaam, Sri Mani Nageswara Temple, Sri EndalaMallikarjunaSwamy Temple and Sri VaasudevaPerumal Temple, the most prominent temples arefirstly Sri Kurmam Shrine with stone inscriptions retrospect with 2nd Century $\mathrm{AD}$; second important destination is Sri Mukhalingam of Lord Shiva temple exists on the banks of river Vamsadhara, an outstanding destination, built around 10th Century AD; finallyArasavalli Sun Temple, is known to have been originally built around 7th Century and reconditioned comprehensively in the last 20 years (http://aptourismsrikakulam.blogspot.com).

In recent years, religious tourism has widely gained credibility in popular parlance (Stausberg, 2011). However, the importance found in the previous research in tourism is even less (Timothy \& Olsen, 2006; Vukonic, 2002). In addition, Okonkwo (2015) entailed that it is recognized recently since certain and significant economic contributions in many nations that have harnessed its potential resources for tourism development. Moreover, many cultural heritage provides considerable contribution to global market commercially, spiritual based tourism is perhaps the least celebrated (Kasim, 2011). The scarcer information and data related to the development of specific tourism with its dynamic nature could be one of the reasons for the underdevelopment of the concept being transformed to economic development. However, the complete opinions of a few managers and a few more tried to utilize the techniques are existed (UNWTO, 2007).

In India, Still a very few researches have done research on the issue of religious tourism development. Researches have not been under taken regarding the e marketing promotions especially on religious tourism focusing on all famous temples. So, unless these have been examined through evaluating the impact on tourists, stakeholders and appropriate measures could be undertaken, ensuring religious tourism development on the site will remain unfulfilled since the technologically accustomed nature of the tourists from all segments is found more with digital attachment. Thus, the researcher was eager to conduct a research on the impact of the e marketing promotions in religious tourism sector with respect to the destinations of Srikakulam district.

\section{OBJECTIVES OF THE STUDY}

The specific objectives of the study are
1. to study the marketing skill application in religious tourism sector with respect to the destinations of Srikakulam district

2. to assess the impact of the e marketing promotions in religious tourism sector with respect to the destinations of Srikakulam district

3. to elevate the ideal combination of e marketing promotions to religious tourism sector.

\section{LITERATURE REVIEW}

Promoting a spiritual destination through social media is challenging enough since the heterogeneous demands in line with the requirements of the religion, place and lifestyle of tourists change time to time. So, it is advised to form a unique strategy to promote certain multi-facet destinations by satisfying different segments of target markets through distinguished channels or networks as well (Schegg et al. 2008)

Social media, being treated as the most congenial tool to promote various kinds of products and services and the religious tourism is not an exception for the same, which is considered highly advisable since interaction and personalization with the tourists or devotees can enable to understand likes and dislikes, which in turn leads to the development of ancillary industries such as hoteliers, restaurants, transports, guides etc. The emergence of Mobile apps have been trending by facilitating certain services like ticketing, lodging, boarding, food, pujas and prasadams (www.hotelschool.cornell.edu). Though there are innumerable social networks increasing time to time by number and features, the popular and promotion intensified networks are Facebook, Google, LinkedIn, Skype, Yelp, Bing, Twitter and Trip Advisor, which have been the value addition in line with different service mix elements. The reviewing sites show more influence since both positive and negative aspects are well exhibited to a significant extent (Rowe, 2011).

The user of reputed social media like twitter and Facebook have been increasing every second the communications have proved that business involvement and promotion related equations have been much through social media (Mangold\&Faulds, 2009).

High significance in grabbing the opportunities of word of mouth and viral marketing through social web is found with a good quantification with two-way communication interaction creation and exchange of user generated content (Tuten, 2008).

It is an amicable opportunity of hospitality industry that enable to develop a partnership for the growth and development of any brand, yet the dangers might be mishandling social media connections and negligence of customer. Now recent trends show that hotels and restaurants have their own websites with search engine optimization and also have mobile apps which keep devotees involved more in the transaction and communication (Witham 2011). 
As per Safko (2010), people are influenced to get engaged in social media for various reasons wherein the uses and gratification approach assumes to be implementable for the tourists use of social media which is appropriate for examine new media types (Muntinga et al., 2010).

Rowe (2005) has contributed certain elements that would leverage the social media i.e. (1) Soliciting endorsements, (2)Maximizing revenue per seat, (3) Bonding with guests, (4)Managing reputation, (5)Reaching out to new customers, (6)Recruiting new staff; and (7)Building a buzz.

Researchers at present study have taken the suitable elements as independent variables for the study as merged in the conceptual framework.

\section{Fig 1: Conceptual Framework}

Independent Variable
\begin{tabular}{|l|}
\hline (1) Soliciting endorsements \\
(2) Delayed and asymmetric message \\
delivery \\
(3) Bonding with guests \\
(4) Managing reputation \\
(5)Reaching new customers \\
(6) Recruiting new staff \\
(7) Building a buzz \\
(8) Strengthening the combination \\
between mobile e-commerce and \\
tourism
\end{tabular}

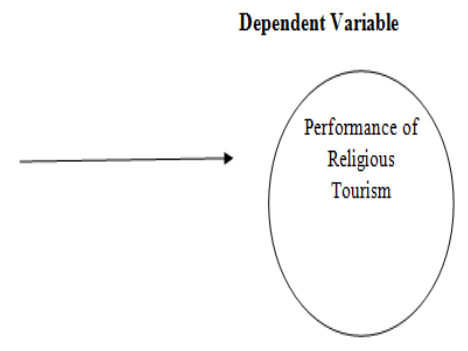

\section{IV.METHODOLOGY}

An exploratory and descriptive type of research through cross sectional research design is adopted and the study was espoused with quantitative approach. To serve the research purpose and achieve the objectives, primary data was collected by using techniques like survey questionnaire, interviews and FGDs. whereas, secondary data collected refers to documents such as books, magazines, research reports, journal article websites etc.

The target populations in the study were digitally habituated devotees (tourists) who can respond to the promotion mix variables being offered by the temples. The questionnaires received from the respondents were 112 where the researcher found a significant number of nonsampling errors.

Data Analysis was accomplished by ANOVA test to see the impact of the independent variables on the efficiency of the religious tourism. The results drawn with the help of SPSS 20 have been analyzed and interpreted that have shown the accustomisation of digital information seeking among different demographical groups of devotees with respect to e-marketing, transportation, accommodation and other celestial activities such as libation and pujas.

\section{ANALYSIS\& RESULTS}

Analysis is made through ANOVA contributing the results to know the impact of e marketing promotion independent variables selected from literature review i e Soliciting endorsements, Delayed and asymmetric message delivery, Bonding with guests, Managing reputation Reaching new customers, Recruiting new staff, Building a buzz and Strengthening the combination between mobile e- commerce and tourism on the Performance of Religious Tourism as dependent variable

Table 5.1 Model Summary

\begin{tabular}{|l|l|l|l|l|}
\hline Model & $\mathrm{R}$ & $\begin{array}{l}\mathrm{R} \\
\text { Square }\end{array}$ & $\begin{array}{l}\text { Adjusted } \\
\text { Square }\end{array}$ & $\begin{array}{l}\text { Rtd. Error of the } \\
\text { Estimate }\end{array}$ \\
\hline 1 & $.403^{\mathrm{a}}$ & .162 & .098 & 1.054 \\
\hline
\end{tabular}

a. Predictors: (Constant), EM1, EM 2, EM 3, EM 4, EM 5, EM 6, EM 7, EM 8

As shown in table 5.1, R Square value is 0.162 which means that all the levels of items in the variable of $\mathrm{e}$ marketing promotion factors are contributing 16.2 per cent in Performance of the religious tourism in Srikakulam district. The remaining 85.8 per cent is being contributed by other unknown variables.

Table 5.2 ANOVA A $^{\mathrm{a}}$

\begin{tabular}{|c|c|c|c|c|c|}
\hline Model & $\begin{array}{ll}\text { Sum } & \text { of } \\
\text { Squares } & \end{array}$ & df & $\begin{array}{l}\text { Mean } \\
\text { Square }\end{array}$ & $F$ & Sig. \\
\hline $\begin{array}{ll} & \text { Regression } \\
1 & \text { Residual } \\
& \text { Total }\end{array}$ & $\begin{array}{l}22.374 \\
115.502 \\
137.876\end{array}$ & $\begin{array}{l}8 \\
104 \\
112\end{array}$ & $\begin{array}{l}2.797 \\
1.111\end{array}$ & 2.518 & $.015^{\mathrm{b}}$ \\
\hline
\end{tabular}

a. Dependent Variable: Performance of the religious tourism in Srikakulam district.

b. Predictors: (Constant), EM1, EM 2, EM 3, EM 4, EM 5, EM 6, EM 7, EM 8

Table 5.2 describes the relationship among Performance of the religious tourism in Srikakulam district and predictors of e marketing promotion performance EM1, EM 2, EM 3, EM 4, EM 5, EM 6, EM 7 and EM 8. The F value between dependent variable and predictors is 2.518, and the significant value is 0.015 which is significant at level of 0.05. It is also noted that there will be the increase of 115.502 in the promotion factors if there is one level in items' increase.

Table 5.3 Coefficients ${ }^{\mathrm{a}}$

\begin{tabular}{|c|c|c|c|c|c|}
\hline \multirow[t]{2}{*}{ Model } & \multicolumn{2}{|c|}{$\begin{array}{l}\text { Unstandardized } \\
\text { Coefficients }\end{array}$} & \multirow{2}{*}{\begin{tabular}{|l|}
$\begin{array}{l}\text { Standardized } \\
\text { Coefficients }\end{array}$ \\
Beta \\
\end{tabular}} & \multirow[t]{2}{*}{$\mathrm{t}$} & \multirow[t]{2}{*}{ Sig. } \\
\hline & B & Std. Error & & & \\
\hline (Constant) & 2.193 & .504 & & 4.353 & .000 \\
\hline $\begin{array}{l}\text { 1. There is Solicit endorsement } \\
\text { from tourists }\end{array}$ & .223 & .085 & .322 & 2.626 & .010 \\
\hline $\begin{array}{l}\text { 2. There are Strengthening } \\
\text { attempts between e- } \\
\text { commerce and tourists }\end{array}$ & -252 & .090 & -357 & -2.788 & .006 \\
\hline $\begin{array}{l}\text { 3. There is bond with tourists } \\
\text { and guests }\end{array}$ & -293 & .118 & -.324 & -2.482 & .015 \\
\hline $\begin{array}{l}\text { 4. There is a good management } \\
\text { of reputation of the temples }\end{array}$ & .174 & .145 & .157 & 1.200 & .233 \\
\hline $\begin{array}{l}\text { 5. There are chances to reach } \\
\text { new tourists }\end{array}$ & .050 & .084 & .066 & .599 & .551 \\
\hline $\begin{array}{l}\text { 6. There are new special } \\
\text { technical resource employees }\end{array}$ & .035 & .097 & .040 & .361 & .719 \\
\hline $\begin{array}{l}\text { 7. There is a big noise through } \\
\text { intemet service }\end{array}$ & .069 & .096 & .087 & .712 & .478 \\
\hline $\begin{array}{l}\text { 8. There is asymmetric message } \\
\text { delivery of tourism } \\
\text { information }\end{array}$ & .153 & .111 & .162 & 1.376 & .172 \\
\hline
\end{tabular}

a. Dependent Variable: Performance of the religious tourism in Srikakulam district.

Published By:

Blue Eyes Intelligence Engineering

\& Sciences Publication 
According to the result drawn from table 5.3, it can be inferred that the first, second and third items of the e marketing promotion factors pertaining to temples i.e. "Solicit endorsement", "Strengthening attempts between ecommerce and tourists" and "bond with tourists and guests" are showing the significance on Performance of the religious tourism in Srikakulam district with $\mathrm{p}$ values of $0.010,0.006$ and 0.015 respectively, which are less than the significance level at 0.05 .

Hence it can be concluded that Performance of the religious tourism in Srikakulam district is affected by "Solicit endorsement", "Strengthening attempts between ecommerce and tourists" and "Bond with tourists and guests". Surprisingly, certain factors found to be important to show the impact i.e management of reputation, reach new tourists, new staff, big noise through internet service and asymmetric message delivery of tourism information do not show any significance.

\section{RECOMMENDATION}

- The endowment department should work in collaboration with the tourism experts and other governmental sectors to get training on minimizing challenges different challenges promoting the religious potentials through digital systems.

- Since "Solicit endorsement", "involvementbetween e-commerce and tourists" and "Bond with tourists and guests are found very important element the temples and the concerned departments should focus on strengthening the same through e marketing promotion mix.

- The departments should focus on the temple for exploring, identifying and conserving the new potentials such as medical tourism (Yoga) and archeological findings.

- At the website of temples, there should be sufficient information regarding temple and its religious activities.

- $\quad$ Provide attention for the use and implementations of opportunities like the tourism strategies, rule and regulations and policies at the religious site.

- $\quad$ Encourage and push the tour and travel operators to promote the religious potentials.

- There should be an opportunity through the institution for the researchers to give credit and explore religious treasures at the religious site.

- $\quad$ Religious tourists are going to the religious website to explore, participate and look the religious potentials. So during this time they should understand the codes of conduct of the website and apply all them well during their search.

- Tourists should be aware about the religious tourism travel tools and equipments to have and travel with before they start to go to the religious site.

- Most of the time during the peak time, there may be problems such as theft/robbery. So religious tourist should keep themselves from such illegal persons and they should public such person while they are looking.

\section{REFERENCE}

1 Cevallos, M. C. (2016). Religious Tourism, Degree Work To Obtain The Professional Title Of National Tourism Guide, Quito-Ecuador.
2 Corp., D. B. (2014). Tourism Business Essentials: Cultural and Heritage Tourism Development.

3 Farhat R. ,Ummara F.,Sundas S. (2016). Religion Tourism And Entrepreneurial Development (A Case Study Hazrat Data Ganj Bakhsh Shrine), South Asian Studies . A Research Journal Of South Asian Studies Vol. 31, No. 1, 275-289.

4 Gurung, R. K. (2016). Marketing Religious Tourism Destination. Case Study: The Birthplace Of Gautama Buddha, Lumbini, Nepal.

5 Kasim, A. (2011). Balancing Tourism and Religious Experience: Understanding Devotees' Perspectives on Thaipusam in Batu Caves, Selangor, Malaysia, Journal of Hospitality Marketing \& Management. 20:3-4, 441-456.

6 Kifle, E. (2014). Challenges of Religious Tourism Development: The Case of Gishen Mariam. Ethiopia American Journal of Tourism Research Vol. 3, No. 2, 42-57.

7 Maryam, Y. T. (ND). Whatsoever he does shall prosper, Psalms chapter 1:3.

8 Melese. (2015). contribution and challenges of Ethiopian orthodox tewahido church for sustainable tourism development: in the case of Gondar city, Gondar university, Ethiopia.

9 Nurhssen.S. (2016). The Role Of Tourism On Local Economic Development Of Gondar City, Amhara Regional State, Ethiopia. J Glob Econ 4: 207.

10 Okonkwo, E. (2015). "Religious Activities and their Tourism Potential in Sukur Kingdom, Nigeria," . International Journal of Religious Tourism and Pilgrimage: Vol. 3: Iss. 1, Article 3.

11 Pintér, A. R. (2014). Religious tourism in Mecca.Saudi Arabia. Budapest Bussiness school,college of commerce, catering and tourism.

12 Robinson, B. ( 2015). Religions of the world: Information about 40 organized religions and faith groups. In: Ontario Consultants on Religious Tolerence. .

13 Stausberg, M. (2011). Religion and Tourism Crossroads, Destinations And Encounters.

14 Tala, M. L. (2014). Dimensions Of Religious Tourism Bucharest Academy Of Economic Studies.

15 UNWTO. (2014). Network of Religious Tourism: international conference on tourism and pilgrimage, project brief held in Spain.

16 UNWTO. (2016). Tourism Highlights Edition.

17 Vukonic, B. (2002). 'Religion, tourism and economics: a convenient symbiosis', Tourism Recreation Research, Vol. 27, No. 2, pp.59-64.

$18 \mathrm{http}: / /$ tourism.gov.in/market-research-and-statistics

19 http://aptourismsrikakulam.blogspot.com/

20 www.hotelschool.cornell.edu 